\title{
DEVELOPING DIGITAL HIGHER EDUCATION IN THE PANDEMIC
}

\author{
Barbara Getto and Franziska Zellweger \\ Zürich University of Teacher Education \\ Lagerstrasse 2 \\ 8090 Zürich, Switzerland
}

\begin{abstract}
This work-in-progress paper presents a project with focus on the role of digital strategies on higher education development in the context of the pandemic situation. During the pandemic, higher education institutions had to switch to distance learning at very short notice. Motivated by the urgency of the external circumstances, digital media were used to a great extent. Numerous empirical studies have examined the experiences of lecturers and students and pointed to potentials and challenges. The steering efforts of higher education management and strategic implications though, have so far been less in focus. This project will contribute to the discourse on how the systematic further development of digitization efforts can take place in a forward-looking manner and what role digitization strategies play in the further development of studies and teaching in the context of the pandemic.
\end{abstract}

\section{KEYWORDS}

Higher Education Development, Digitization, Digital Strategies, Post Pandemic Development

\section{INTRODUCTION}

The drastic conversion of face-to-face teaching to distance learning in the wake of the corona pandemic has been accomplished surprisingly quickly and extensively in the higher education landscape. What e-learning specialists had worked towards (more or less) successfully in years of effort was now suddenly possible: Many faculty members have committed themselves to the new tools and have adapted their teaching to the new circumstances. Digital infrastructures were further expanded. In the meantime, it is becoming apparent that the sanitary situation will at least partially allow a return to the campuses soon and the question arises: What will remain of this exceptional experience? Numerous empirical studies have examined the experience of faculty and students and pointed to potentials and challenges. The steering efforts of leaders and strategic implications have received less attention to date. The outlined project is intended to contribute to the discourse on how the systematic further development of digitization efforts can be pursued and what role strategies for digitization play in the further development of higher education in the context of the pandemic.

\section{HIGHER EDUCATION DEVELOPMENT IN THE CONTEXT OF THE PANDEMIC}

\subsection{The Significance of Digitization Strategies}

Research on digitization in education has made it clear that digitalization in higher education institutions means an organizational change process that requires a range of measures at different levels (e.g., Seufert et al, 2015). Digitization in higher education is more than the introduction of certain technologies and new teaching methods (Castañeda \& Selwyn, 2018). Projects as individual measures and associated investments do not contribute sufficiently to higher education development if they are not integrated into an overarching strategy that is 
anchored in the organizational development goals (Kerres \& Getto, 2015). Therefore, higher education institutions are advised to pursue digitization along the lines of higher education development (Kerres \& Getto, 2017).

During the pandemic, however, higher education institutions had to transition to distance learning on very short notice. Motivated by the urgency of external circumstances, the use of digital media occurred almost across the board. A distinction is made between digitally supported teaching and so-called "emergency remote teaching" (Hodges et al, 2020). Nevertheless, the question arises, what influence the experiences from the pandemic will have on the design of higher education in the context of digitization. In this context, we are particularly interested in the extent to which strategic principles guided the way in which this emergency was managed and in what way the experiences are incorporated into the strategic discourse.

\subsection{Disruption by the Pandemic?}

Findings from many empirical studies on the effects of the pandemic indicate that teaching operations could be maintained in spring 2020 with moderate difficulties in organization (Karapanos, Pelz, Hawlitschek, \& Wollersheim, 2021). Students appreciated the flexibility of online learning but missed the contact with instructors and fellow students. Mulders and Krah (2021, p. 40) note that preferences for synchrony, self-structuring, collaboration, and digital lectures seem to vary widely among students. However, students are exposed to different degrees of financial and health burdens. (Rüegg \& Eggli, 2020). Research in the field of teacher education indicates that most students could organize themselves well, but they describe their learning processes as rather superficial. Thereby, the heterogeneity of the experience is high. A dichotomous comparison of online vs. presence or synchronous vs. asynchronous or the question of the optimal mixture does too little justice to the complexity of the design task. Thus, the increased control of learning processes via assignments to be completed in self-study is very presuppositional both regarding the learning and working strategies of the students as well as the didactic preparation by the lecturers (Zellweger \& Kocher, in press).

Different actors look back on this special period from different perspectives. Interpretations of the "emergency remote teaching" experience and discussions about the "new normal" have begun. What (strategic) considerations are higher education institutions using to shape the digitization of teaching and learning post Corona? This project follows strategic actors a few steps on the way out of the crisis towards a new normal.

\section{RESEARCH QUESTIONS AND METHODOLOGICAL APPROACH}

Based on the preceding considerations, we derive the following research questions:

What is the role of higher education digital strategies in coping with the pandemic?

Which strategic developments regarding the digitization in education can be observed post-pandemic and how are they motivated?

Under what conditions does strategy work support the further development of university teaching?

With this project, the need for action is to be identified and discussed with stakeholders in the higher education system to further develop framework conditions (in terms of structures and processes) for future-oriented teaching in the context of digitization. The methodical approach is planned in two phases:

Phase 1 (06-09 / 2021): Semi-structured interviews

In the transition between the end of the spring semester and the beginning of the autumn semester 2021, 7 interviews were conducted with experts in higher education institutions in Germany and Switzerland who hold management positions for teaching and further education or are responsible for university wide digitization initiatives.

For the selection of the interviewees, it was crucial that the persons in their function are closely involved in the strategic development of the university and at the same time are well acquainted with the operational challenges. In addition, attention was paid to a variety of perspectives based on the profile of the university as well as the people. 
The discussions were analyzed using the "content structuring qualitative method" according to Kuckartz (2018, p. 97ff which suggests a sequence of deductive and inductive coding. For the first deductive coding, 13 main categories were defined in the three areas of strategy, digitization, processes / roles. In the following, sub-categories are inductively developed and condensed on the material within the main categories.

\section{Phase 2 (10-12 / 2021): reflection and consolidation in focus groups}

In the second phase, the results of the analysis are discussed and deepened with the interview partners as well as other experts in focus groups (Schultz et al., 2012).

It is also planned to repeat the interviews in the period in January 2022 when the planning of the spring semester is ongoing in order to trace how the discourse has developed over time. Are there new goals, what are they? Have expectations been met? What are current discussions? Reflection on decision-making? The analysis of these discussions is again made available and deepened in focus groups.

\section{PRELIMINARY RESULTS AND PERSPECTIVES}

Studies show that the measures implemented in the short term during the pandemic enabled higher education institutions to continue operating (Karapanos, Pelz, Hawlitschek, \& Wollersheim, 2021). It is assumed that these activities are not so much part of a profile-building strategy for higher education development, but rather focus on digitization itself. In many cases, therefore, established classroom formats are translated one-to-one into digital courses.

From the observation of the discussions at higher education institutions, it can be assumed that the measures for implementing digital teaching since the beginning of the pandemic have been less guided by strategies or aimed at a long-term planning horizon.

Initial results of the analysis of the interview data indicate that the abrupt switch to emergency remote teaching at universities with elaborate digitization strategies went relatively smoothly. They were able to rely on an already well-developed technical infrastructure. In addition, universities in which a strategic discourse on digitization in education had already started were able to build on existing discussions and use established exchange and support structures and expand them as required.

In all universities in the sample, when switching to emergency remote teaching, reported high agility and willingness to cooperate within their own institution as well as across universities. With the duration of the pandemic, however, it also becomes apparent that there is primarily a great learning effect in the use of digital media. Didactic innovations, which also go hand in hand with a change of attitude, occurred far less. Decisions regarding digitization in the context of teaching and further education were not made with regard to long-term strategic perspectives during the pandemic. Rather, it was about keeping teaching operations going.

Under the impressions of the special situation since the beginning of the pandemic, an increased willingness to change was recorded. Wanting to use this as potential for the further development of university teaching is a frequently expressed wish. On the other hand, there are concerns about a sudden breakdown in developments if the framework conditions change. The pandemic situation as well as political decisions have a direct influence on the structuring options of the actors at the universities. For example, the decision of various federal states to plan the autumn semester "on campus" deprives university management of arguments to lead teachers in the direction of future-oriented blended learning concepts.

In retrospect, the adaptability of the actors was formulated as the most impressive insight during the pandemic. However, the question arises as to how sustainably this radical experience can be translated into innovation in teaching and learing. In the further analysis, the focus should therefore primarily be on the question under which conditions a qualitative development can take place and which pedagogical, technological, organizational, socio-cultural and economic aspects are of particular importance (Seufert \& Euler, 2003). 


\section{REFERENCES}

Castañeda, L., \& Selwyn, N., 2018. More than tools? Making sense of the ongoing digitizations of higher education. International Journal of Educational Technology in Higher Education, 15(1), 22. https://doi.org/10.1186/s41239-0180109-y

Hodges, C.B. et al, 2020. The Difference Between Emergency Remote Teaching and Online Learning. Educause Review: https://er.educause.edu/articles/2020/3/the-difference-between-emergency-remote-teaching-and-online-learning

Karapanos, M., et al, 2021. Hochschullehre im Pandemiebetrieb: Wie Studierende in Sachsen das digitale Sommersemester erlebten. MedienPädagogik: Zeitschrift für Theorie und Praxis der Medienbildung, pp 40, 1-24.

Kerres, M. \& Getto, B., 2015. Vom E-Learning Projekt zur nachhaltigen Hochschulentwicklung: Strategisches Alignment im Kernprozess „Studium \& Lehre“. In A. Mai (Hrsg.), Hochschulwege 2015. Wie verändern Projekte die Hochschulen? Dokumentation der Tagung in Weimar am 8.-9. März 2015. Weimar.

Kerres, M. \& Getto, B., 2017. Akteurinnen/Akteure der Digitalisierung im Hochschulsystem: Modernisierung oder Profilierung? In: Zeitschrift für Hochschulentwicklung 12, pp. 123-142. Retrieved from: http://www.zfhe.at/index.php/zfhe/article/view/973

Kuckartz, U. (2018). Qualitative Inhaltsanalyse. (4 Aufl.). Weinheim: Beltz Juventa.

Mulders, M., \& Krah, S., 2021. Digitales Lernen während der Covid-19-Pandemie aus Sicht von Studierenden der Erziehungswissenschaften: Handlungsempfehlungen für die Digitalisierung von Hochschullehre. MedienPädagogik: Zeitschrift für Theorie und Praxis der Medienbildung, 40, pp. 25-44.

Rüegg, R., \& Eggli, A., 2020. COVID-19-Studierendenbefragung. Bericht der Berner Fachhochschule zur «International COVID-19 Student Well-being Study». Retrieved from https://doi.org/10.5281/zenodo.4422660

Schulz, M., Mack, B. \& Renn, O. (Hrsg.). (2012). Fokusgruppen in der empirischen Sozialwissenschaft. Wiesbaden: Springer.

Seufert, S., \& Euler, D. (2003). Nachhaltigkeit von e-learning Innovationen. (SCIL Arbeitsbericht 2). Universität St. Gallen.

Zellweger, F., \& Kocher, M. (in Press). Das Engagement von Lehramtsstudierenden im Distance Learning im Frühling 2020. MedienPädagogik: Zeitschrift für Theorie und Praxis der Medienbildung. 